Acta vet. scand. $1964,5,394-403$.

From the Medical Department for Non-Ruminants, Royal Veterinary

College, Stockholm.

\title{
ELECTROCARDIOGRAPHIC EXAMINATIONS \\ IN DOGS WITH EXPERIMENTAL HEPATITIS CONTAGIOSA CANIS*)
}

\section{By}

Gert Lindblad

In his comprehensive study on Hepatitis contagiosa canis (H.c.c.) Rubarth (1947) describes the myocardial changes as follows: The myocardium almost regularly showed a loose structure with the different muscle fibres separated from one another; this was due to an oedema which was also seen subendocardially; at the base of the aortic valves the oedema had often assumed such proportions that it was distinctly visible even at the macroscopical examination. In the available literature only one case of H.c.c. can be found in which electrocardiographic examination has been made (Lannek 1949).

As the pathogenesis of H.c.c. has not yet been made clear, it may be of interest to find out whether a heart-failure reflected in the electrocardiogram can be thought to contribute to a lethal course.

The demonstrated electrocardiographic changes will also be discussed in relation to the serum-electrolyte values.

\section{MATERIAL AND METHODS}

17 dogs lacking antibodies (Espmarck \& Sahlenstedt 1960) were used, they were of mixed breed, males and females, and their ages ranged from 3 to 6 months. Seven of the dogs (nos. 10-16) were reared without colostrum. The inoculation was in all the cases made

*) Supported by grants from "Anslag för främjande av medicinsk forskning vid Veterinärhögskolan". 
by the intraperitoneal route, $4 \mathrm{ml}$ of undiluted virus culture being injected. The virus material used was a strain $\mathrm{E} 745$ isolated from a fatal spontaneous case of H.c.c. ${ }^{*}$ ), titre 6.5 TCID $_{50} / \mathrm{ml}$ (Persson et al. 1961).

The development of disease was followed as described earlier (Lindblad \& Persson 1962). The electrocardiographic examinations were made with a direct writing, four-channel recorder (Mingograf Cardirex $42 \mathrm{~B}$ ). Leads I, II, III, $\mathrm{CR}_{5}, \mathrm{CR}_{6 \mathrm{~L}}$, and $\mathrm{CR}_{6 \mathrm{U}}$ were registered (Lannek 1949). Frequent recordings were made in 12 dogs. The haematocrit values were followed in 16 dogs. The serum-electrolytes $\mathrm{K}, \mathrm{Na}, \mathrm{Ca}, \mathrm{P}$, and $\mathrm{Cl}$ were observed in 14 dogs.

The following laboratory procedures were used in the determinations :

Potassium and sodium: Flame photometry, using the E.E.L. flame photometer.

Calcium: $\quad$ Method of Thalme (1963).

Phosphorus: $\quad$ Method of Taussky \& Shorr (1953).

Chlorides: Method of Brun (1949).

Heamatocrit determination: This was carried out with the "Kemila" haematocrit centrifuge (type 543) by centrifugation of heparinized whole blood for 5 minutes at $12,000 \mathrm{rpm}$.

\section{RESULTS}

The clinical picture was fairly uniform in all the dogs as regards such symptoms as vomiting, diarrhoea, loss of appetite, apathy, and polydipsia. The temperature recordings and the values for total leucocyte counts, glutamic-oxaloacetic transaminase (G.O.T.), and ornithine carbamyl transferase (O.C.T.) are listed in table 1 . In most cases the haematocrit changes very little over the first 5 days after the inoculation. Thereafter, a slow decrease can be noted, with values down to $25 \% 10$ to 12 days after inoculation. This agrees with Coffin \& Cabasso's (1953) observations.

Before the 3rd day after inoculation the electrocardiogram showed no deviations from the normal picture. The results of all the recordings on and after the 3rd post-inoculation day are shown in table 2. The following deviations will be seen: Shifting of the T-amplitude and depression of the $\mathrm{ST}_{\mathrm{J}}$ and S-T segments.

The results of the electrolyte determinations are shown in fig. 1. A comparison between the mean value for our own normal material $(n=23)$ and the mean value for the results of the

*) The strain was isolated by M. Sibalin, V.M.D., Department of Medicine, Royal Veterinary College, Stockholm. 
Table 1 .

\begin{tabular}{|c|c|c|c|c|c|c|c|}
\hline \multirow{2}{*}{\multicolumn{2}{|c|}{ Dog no. }} & \multirow{2}{*}{$\begin{array}{c}\text { G.O.T. } \\
\text { value }\end{array}$} & \multirow{2}{*}{$\underset{\substack{\text { O.C.T. } \\
\text { value }}}{\text { aximum }}$} & \multirow{2}{*}{$\begin{array}{l}\text { Total leuco- } \\
\text { cyte count } \\
\text { maximum } \\
\text { value }\end{array}$} & \multirow{2}{*}{$\begin{array}{c}\text { Temperature } \\
{ }^{\circ} \mathrm{C} \\
\text { maximum } \\
\text { value }\end{array}$} & \multicolumn{2}{|c|}{ Examination } \\
\hline & & & & & & E.C.G. & $\begin{array}{c}\text { electro- } \\
\text { lyte } \\
\text { studies }\end{array}$ \\
\hline 1 & & $++(6)$ & $+(5)$ & $4400(5)$ & $41.0(3.5)$ & + & + \\
\hline 2 & & $+(3.6)$ & - & $5700(5)$ & $41.4(5)$ & - & + \\
\hline 3 & & $+++(7)$ & $+(10)$ & $2700(5)$ & $41.2(3.6)$ & - & + \\
\hline 4 & & $+++(6)$ & $+++(6)$ & $3500(5)$ & $41.4(3)$ & - & + \\
\hline 5 & & $+(3)$ & - & $4800(5)$ & $41.1(5)$ & - & + \\
\hline 6 & & $+(5.6)$ & $+(5)$ & $4100(5)$ & $41.4(3)$ & + & + \\
\hline 7 & & $+++(7)$ & $++(10)$ & $2200(5)$ & $41.0(3)$ & + & + \\
\hline 8 & & $+(6)$ & - & $3400(5)$ & $40.7(3)$ & + & + \\
\hline 9 & & + & - & $5300(3)$ & $40.4(3)$ & - & + \\
\hline 10 & Died (4) & $+(3)$ & - & $3300(3)$ & $40.0(3)$ & + & + \\
\hline 11 & & $+++(5)$ & $+++(6)$ & $2200(5)$ & $40.5(3)$ & + & + \\
\hline 12 & & $+++(5)$ & $+++(6)$ & $2000(5)$ & $40.3(5)$ & + & + \\
\hline 13 & Died (4) & $+(3)$ & $+(3)$ & $6200(3)$ & 39.9 (3) & + & + \\
\hline 14 & , (4) & $+(3)$ & $++(3)$ & 12400 & $39.5(3)$ & + & + \\
\hline 15 & " (5) & $+++(4)$ & $+++(4)$ & $2400(3)$ & $40.3(2)$ & + & - \\
\hline 16 & & $+(6)$ & $+(4)$ & $1800(3)$ & $41.2(3)$ & + & - \\
\hline 17 & & - & - & & $40.5(5)$ & + & - \\
\hline
\end{tabular}

Figures in parentheses indicate day after inoculation.

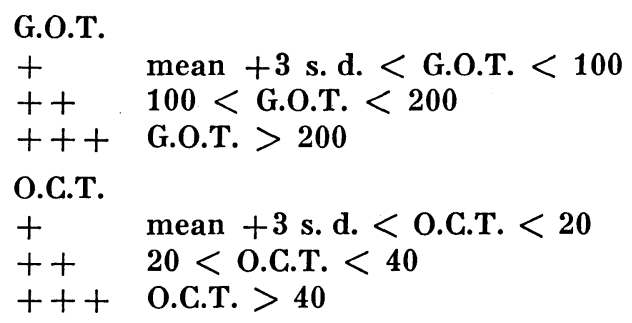

electrolyte studies on days $3,5,7$, and 9 after inoculation, using Student's t-test, shows no differences with respect to phosphorus and calcium.

As regards sodium, there is a difference on the $3 \mathrm{rd}, 5 \mathrm{th}, 7 \mathrm{th}$, and 9 th post-inoculation days $(\mathrm{P}<0.001)$. For potassium, the same test gives a deviation on the 3rd and the 5th day after inoculation $(\mathrm{P}<0.001)$ and on the 7 th day after inoculation $(0.01>\mathrm{P}>0.001)$. On the 9 th day after inoculation there is no difference. With respect to chlorides, a deviation from the normal value is seen only on the 5th day after inoculation $(0.05>\mathrm{P}>$ 0.02 ). 


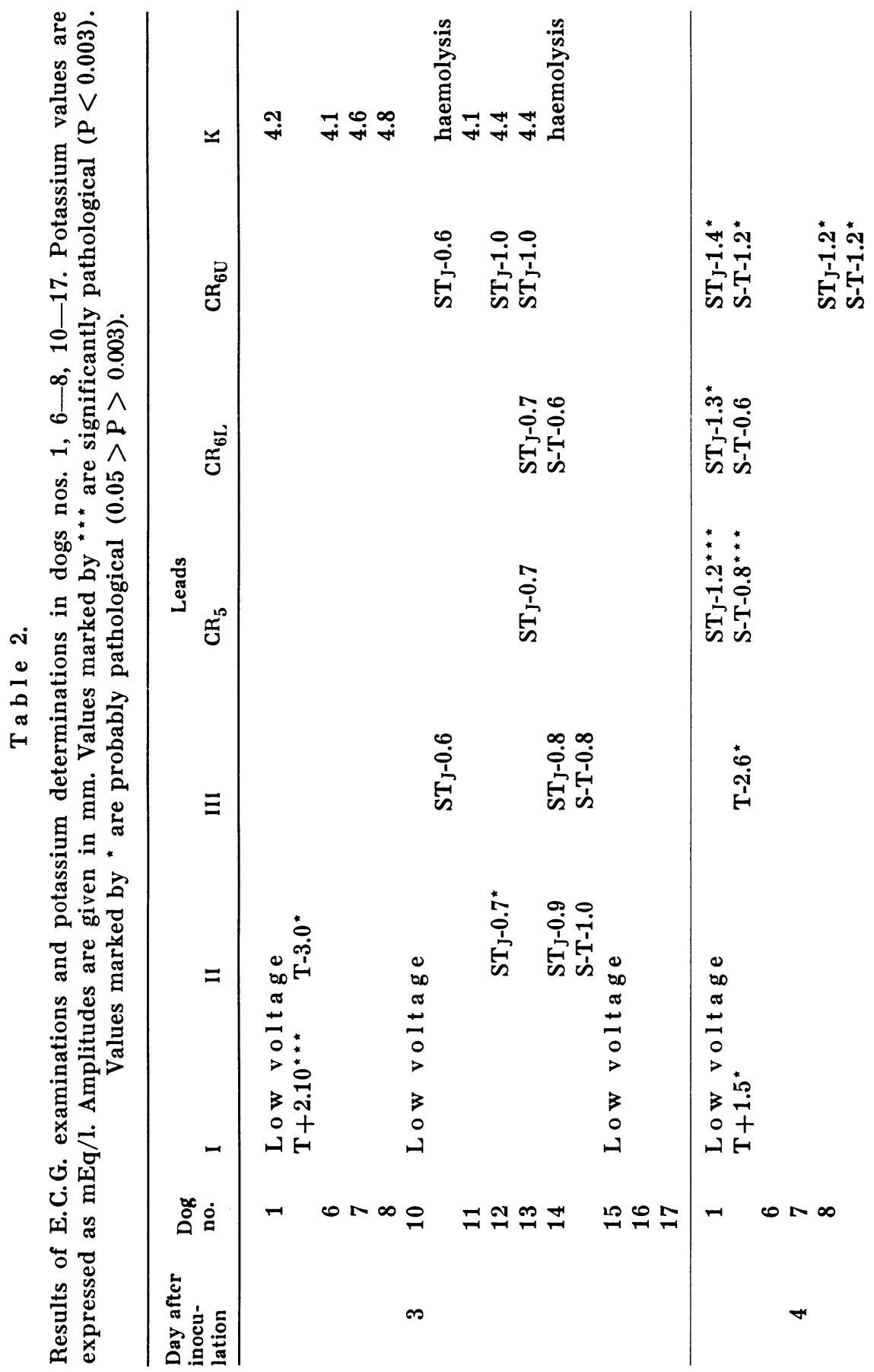




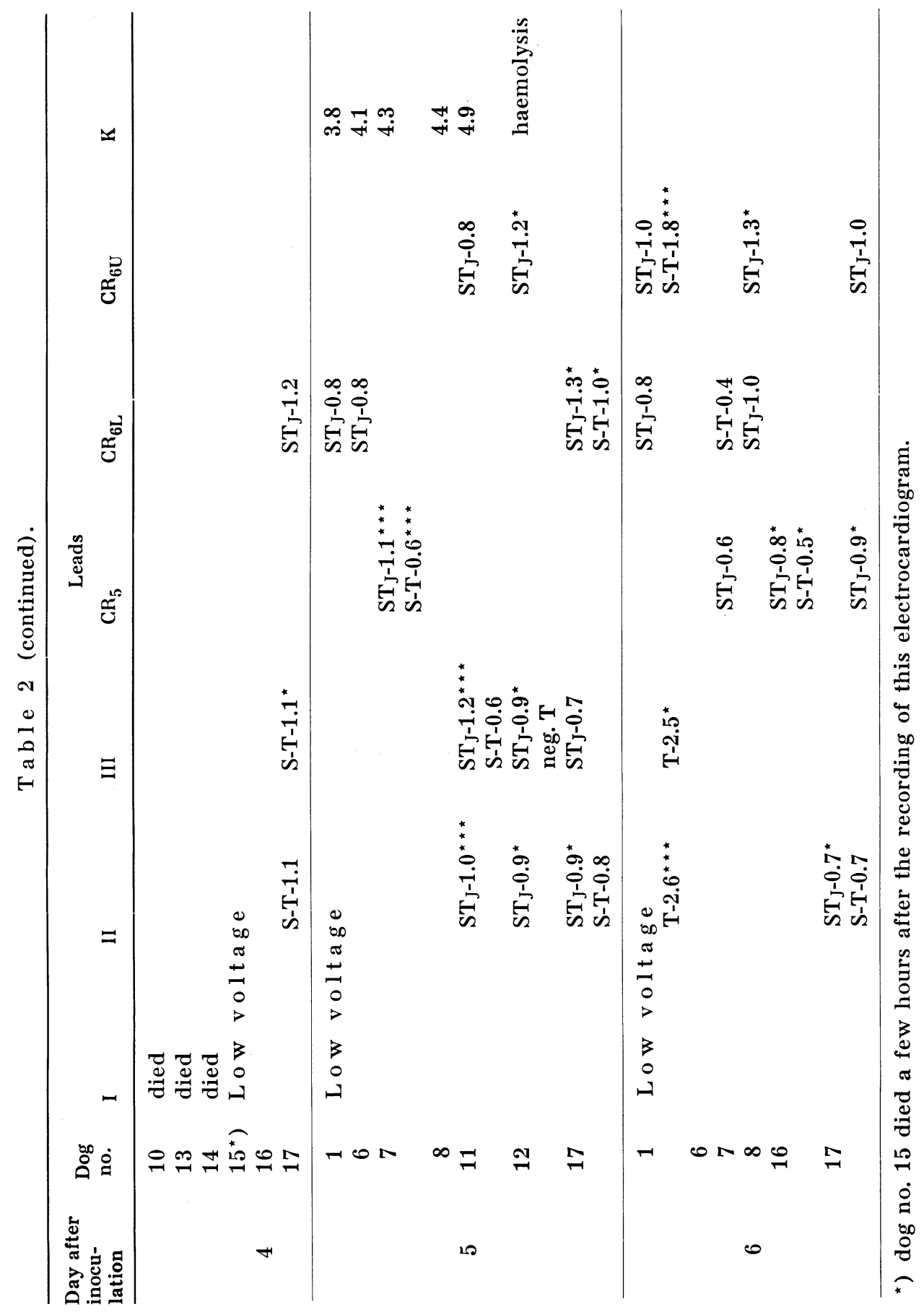




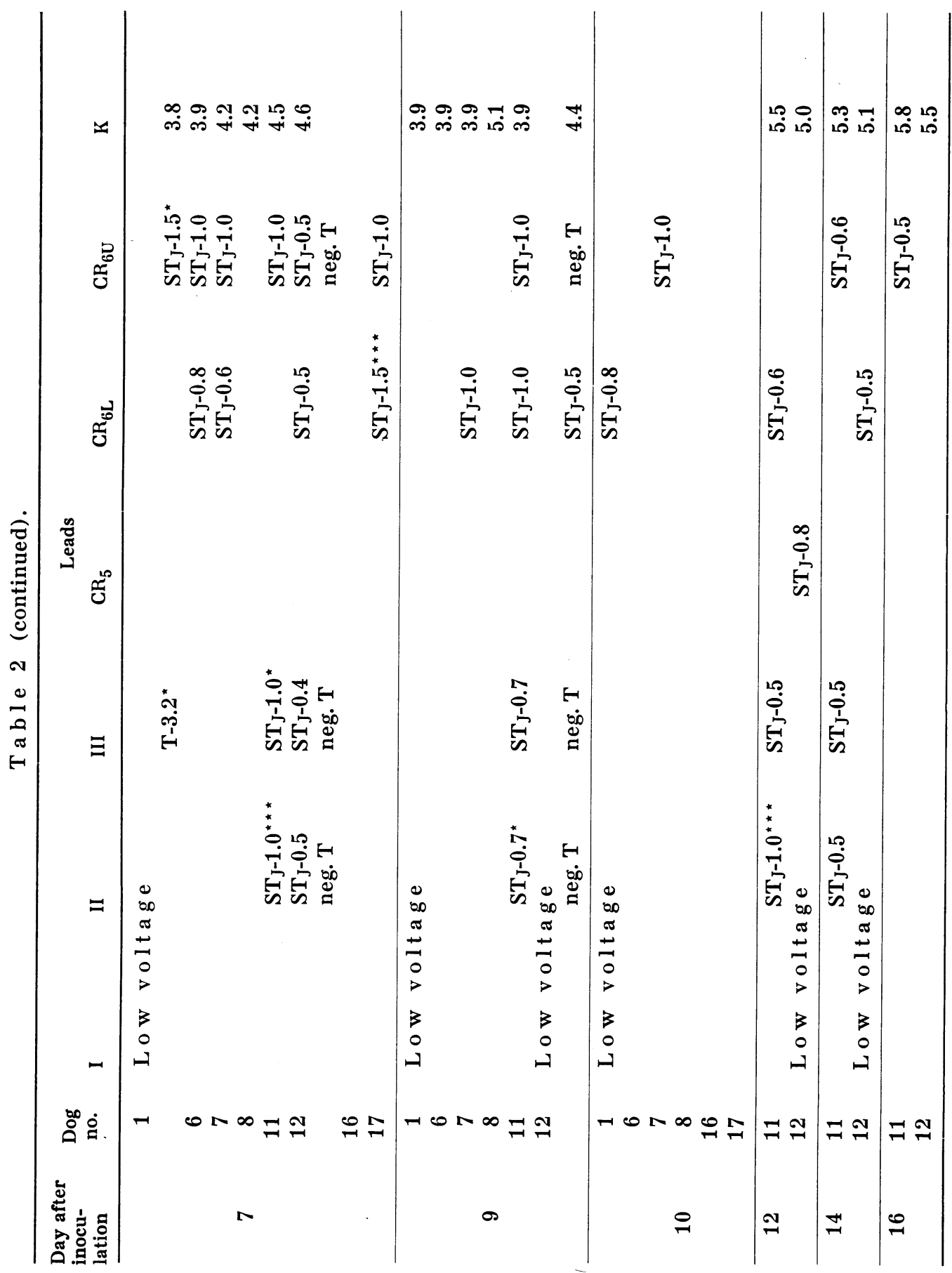




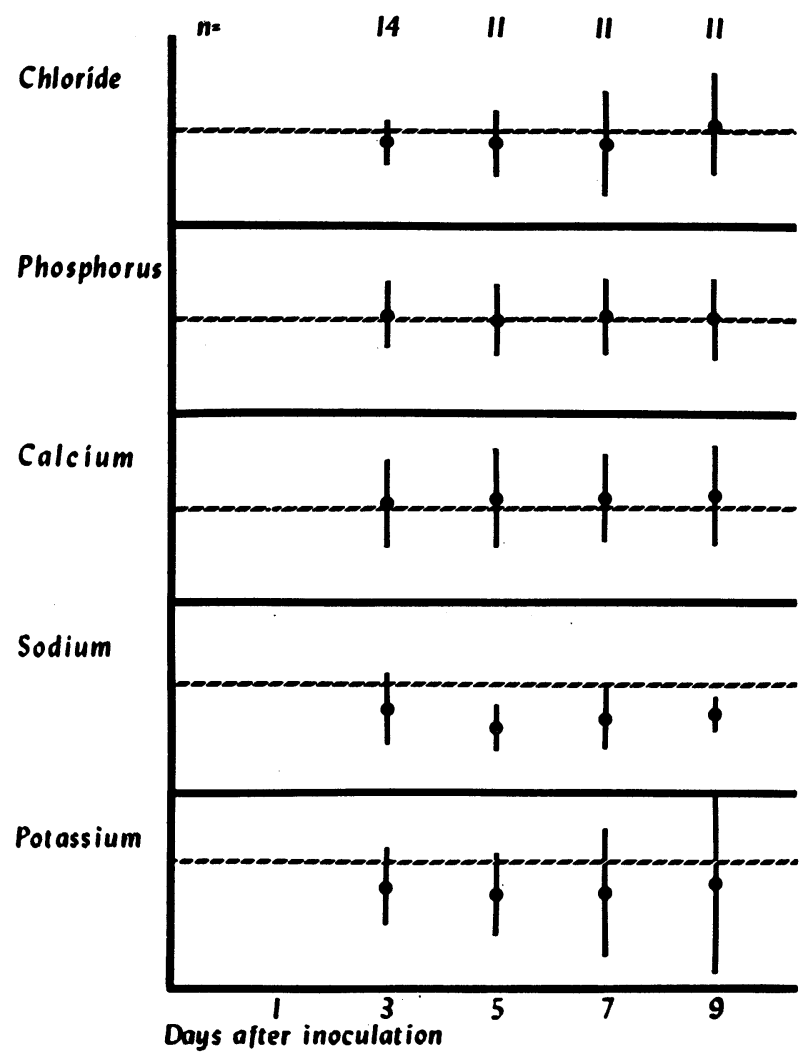

F i g. 1. Results of electrolyte studies. The broken lines indicate mean values for a normal material of 23 dogs. The normal material includes values obtained from 5 of the dogs before inoculation. The preinoculation sera from 9 dogs were lost by accident.

i indicates the mean value for inoculated dogs \pm 2 s. d.

\section{DISCUSSION}

Changes in the ion constitution in the cells of the heart and in the fluid that surrounds them can be reflected in the electrocardiogram. Abnormal calcium and potassium values are considered to cause the greatest deviations. Hypokalaemia gives, for instance, depression of the S-T segment and changes in the T-amplitude (Goldberger 1954, Bellet 1955). Similar deviations can also be seen in myocarditis and in hypoxaemia associated with circulatory disturbances (Goldberger 1954, Bellet 1955, Goldman 1956). 
In the present study slightly lowered serum-potassium values were noted. The question may therefore be raised whether this decrease could have caused the observed electrocardiographic changes, which consisted exactly of depression of the S-T segment and deviations in the $T$-wave. It will be seen from table 2, however, that there is no correlation in time between the decreases of potassium and the electrocardiographic changes. Moreover, the decreases in serum-potassium are fairly small, the lowest value being $3.8 \mathrm{mEq}$ per litre. These facts definitely favour some other cause of the electrocardiographic changes.

A generalized circulatory disturbance is present in H.c.c. (Lindblad, Brånemark \& Lindström, 1964). In severe cases it can lead to complete cessation of flow in some capillaries. As regards the myocardium, such a disturbance could produce the electrocardiographic changes seen in ischaemic conditions, namely S-T depression and deviations of the T-wave (cf. Schaefer 1951). In addition, the morphological changes which have been demonstrated in H.c.c. (Lindblad \& Björkman 1964) and the associated change in permeability should also play a part in causing a metabolic disturbance in the myocardium. In view of the fact that myocarditis has not been demonstrated in H.c.c. (Rubarth 1947), it must be considered probable that the aforementioned changes in circulation and permeability are responsible for the observed electrocardiographic abnormalities.

The question whether the decrease in the serum-electrolyte values is ascribable to a depletion or merely to a change in concentration, that is, increased water in the plasma, or two both these factors, requires further investigation. A possibility which cannot be excluded is that sodium, potassium, and chlorides may decrease through the vomiting and diarrhoea; nor can the possibility of hydration because of the polydipsia be excluded (Bland 1956, Thordal-Christensen 1957, Thorén 1960).

The observed lowering of the haematocrit can have been associated with such a hydration, but can of course have been due to a reduction of the erythrocyte volume in the blood. 


\section{REFERENCES}

Bellet, S.: The electrocardiogram in electrolyte imbalance. Arch. Intern. Med. 1955, 96, 618-638.

Bland, J. H.: Disturbances of fluid balance. 2nd Ed. W. B. Saunders \& Co. Philadelphia \& London 1956.

Brun, C.: Klorbestemmelse. En mikrometode. Nord. Med. 1949, 42, $1774-1776$.

Espmarck, J. A. \& Salenstedt, C. R.: Haemagglutination-inhibition test for titration of antibodies against Hepatitis contagiosa canis (Infectious Canine Hepatitis). Arch. ges. Virusforsch. 1961, 11, $64-72$.

Goldberger, E.: Unipolar lead electrocardiography and vectorcardiography. 3rd Ed. Lea \& Febiger. Philadelphia 1954.

Goldman, M. J.: Principles of clinical electrocardiography. Lange Medical Publication, Los Altos California 1956.

Lannek, N.: A clinical and experimental study on the electrocardiogram in dogs. Ivar Häggströms Boktryckeri AB Stockholm 1949.

Lindblad, G., Brånemark, P. I. \& Lindström, J.: Capillary form and function in dogs with experimental Hepatitis contagiosa canis. An intravital microvascular study. Acta vet. scand. 1964, 5, $384-393$.

Lindblad, G. \& Björkman, N.: Ultrastructural alterations in sinusoidal endothelium of liver and bone marrow in dogs with experimental Hepatitis contagiosa canis. Acta path. microbiol. scand. In press.

Lindblad, G. \& Persson, $F .:$ Transaminase and transferase activities in blood plasma of dogs with experimentally produced Hepatitis contagiosa canis (H.c.c.). Acta vet. scand. 1962, 3, 378-390.

Persson, F., Persson, S. \& Sibalin, M.: The aetiological role of Hepatitis contagiosa canis (H.c.c.) in chronic nephritis in dogs. Acta vet. scand. $1961,2,137-151$.

Rubarth, S.: An acute virus disease with liver lesions in dogs. (Hepatitis contagiosa canis). Acta path. microbiol. scand. Suppl. 69, 1947.

Schaefer, H., Das Elektrokardiogram. Theorie und Klinik. Springer Verlag, Berlin, Göttingen und Heidelberg. 1951.

Taussky, H. H. \& Shorr, E.: A microcolorimetric method for the determination of inorganic phosphorus. J. Biol. Chem. 1953, $202,675-685$.

Thalme, B.: A system of microliter methods suitable for routine clinical work. Acta med. scand. 1963. Suppl. 174.

Thorén, L.: Vätskebalans. Almqvist \& Wicksells Boktryckeri AB, Uppsala, 1960.

\section{SUMMARY}

Dogs with experimentally produced Hepatitis contagiosa canis were subjected to repeated electrocardiographic examinations during the course of the disease. Varying degrees of depression of the $\mathrm{ST}_{\mathrm{J}}$ and S-T segments and deviations of the T-wave were noted. Serum- 
electrolyte studies made during the illness showed a decrease of potassium, sodium, and chlorides which did not seem to be the cause of the observed electrocardiographic abnormalities. Circulatory disturbances and changes in the endothelial cells described elsewhere are considered to be the cause of a disturbance in the metabolism and the function of the myocardium with resulting depression of the $\mathrm{ST}_{\mathrm{J}}$ and $\mathrm{S}-\mathrm{T}$ segments and deviations of the T-wave.

\section{ZUSAMMENFASSUNG}

\section{(Elektrokardiographische) EKG-Untersuchungen an Hunden mit} experimenteller Hepatitis contagiosa canis.

Hunde mit experimentell hervorgerufener H.c.c., wurden während des Krankheitsverlaufes wiederholt elektrokardiographisch untersucht. Man hat verschieden starke Senkungen vom ST J $_{\text {und }}$ S-TSegment als auch Veränderungen der T-Welle beobachtet. Die gleichzeitig vorgenommenen Untersuchungen der Serumelektrolyte zeigen K-, Na- und Gl- Senkungen, die jedoch nicht als Ursache der beobachteten EKG-Veränderungen aufgefasst werden. Die in anderen Arbeiten beschiebenen Kreislaufstörungen und die Schädigungen des Endothels, werden als Ursache des veränderten Stoffwechsels und von Funktionsstörungen im Myokard mit Senkung des STJ und S-T- Segments und T-Wellen-deviation aufgefasst.

\section{SAMMANFATTNING}

EKG-undersökningar på hundar med experimentell Hepatitis contagiosa canis.

På hundar med experimentellt framkallad H.c.c. har under sjukdomsutvecklingen upprepade EKG-undersökningar företagits. Varierande grad av sänkninger av $\mathrm{ST}_{J}$ och S-T segment och förändringar av T-vågen har konstaterats. Parallellt företagna serumelektrolytundersökningar visar $\mathrm{K}$-, Na- och Cl- sänkningar, vilka dock icke synes vara orsak till de konstaterade EKG-förändringarna. I andra arbeten beskrivna cirkulationsrubbningar och endotelcellskador, anses vara orsak till ändrad metabolism och funktionsstörning i myokardiet med sänkning av $\mathrm{ST}_{\mathrm{J}}$ och $\mathrm{S}$-T segment och T-vågsdeviationer som följd.

(Received February 8. 1964). 